\title{
Clinical Microbiology: Open
}

\section{Signals Controlling Extracellular Trap Formation in Plant and Animal Immune Responses}

\author{
Gilberto Curlango-Rivera ${ }^{1}$, Yolanda Flores-Lara ${ }^{2}$, Ihnbae Cho ${ }^{3}$, David A Huskey ${ }^{1}$, Zhongguo Xiong ${ }^{4}$ and Martha C Hawes ${ }^{1 *}$ \\ "Corresponding author: Martha C Hawes, Department of Soil, Water and Environmental Sciences, University of Arizona, USA, Tel: 520-621-5490; Email: \\ mhawes@u.arizona.edu
}

${ }^{1}$ Department of Soil, Water and Environmental Sciences, University of Arizona, USA

2 Universidad de Sonora Unidad Regional Norte Caborca, Mexico

${ }^{3}$ Department of Molecular \& Cellular Biology, University of Arizona, Tucson AZ, USA

${ }^{4}$ School of Plant Sciences University of Arizona, Tucson, AZ, USA

Rec date: Jul 01, 2014; Acc date: Aug 26, 2014; Pub date: Sep 04, 2014

Copyright: (c) 2014 Curlango-Rivera G, et al. This is an open-access article distributed under the terms of the Creative Commons Attribution License, which permits unrestricted use, distribution, and reproduction in any medium, provided the original author and source are credited.

\begin{abstract}
Newly characterized defence processes based on extracellular DNA-based trapping in mammals point to new targets for control of diseases ranging from lupus to sepsis to cancer. Emerging evidence that this is an ancient underpinning of immune systems includes the observation that DNA-based extracellular traps also operate in plants. Potential clinical applications include the use of plant metabolites as signals to modulate plant and animal extracellular trapping responses.
\end{abstract}

Keywords: Root border cells; Extracellular trapping; NETs; ExDNA

\section{Commentary}

In 2004, neutrophil extracellular traps (NETs) were first reported to be a component of the mammalian immune system [1]. In response to microbial challenge, neutrophils produce and export a macromolecular complex that functions as a trap to immobilize the invading pathogen [2]. Extracellular DNA (exDNA) is a structural component of NETs, such that treatment with DNase eliminates the capacity of cells to control microbial invasion $[3,4]$. Rapid progress in describing the role of exDNA-based trapping in defense by neutrophils, eosinophils, and other cell types and its interaction with bacterial, fungal, viral, and protozoan pathogens is underway [5-8]. ExDNA also has been implicated in autoimmune diseases including lupus, rheumatoid arthritis, and cancer [9-11]. It is now clear that exDNA plays a critical role in cellular defense in animals, and that microbial expression of extracellular DNase (exDNase) is a key virulence factor in pathogenesis [12-15]. The human pathogen Group A Streptococcus has been known for decades to produce exDNases; all strains produce at least one, and most produce several whose expression is induced by contact with host cells [16]. A strong correlation between virulence and exDNase production among strains was presumed to be a nonspecific scavenging mechanism unrelated to pathogenicity. As one example of such a correlation, exDNase is produced by all tested pathogenic strains of Fusobacterium necrophorum, but closely related nonvirulent strains do not express this trait [17]. Fungal pathogens of mammals also secrete exDNase, whose levels are correlated with virulence [18].

A phenomenon of microbial 'extracellular trapping' also occurs in plant cells called 'border cells' (Figure 1). These specialized cell populations regulate microbial colonization of root tips housing meristems that control plant growth and development [19]. As with mammalian bone marrow cells that produce neutrophils, the root cap is programmed to produce a set number of border cells [20-22]. In response to signals including pathogens, metals, and other elicitors, cell cycle is induced, renewed mitosis is initiated, and new cells begin to detach into the environment within 5 minutes [23,24]. In a survey of $>50$ diverse monocot, dicot and gymnosperm species, association of the plant pathogen Agrobacterium tumefaciens with border cells of each plant was correlated with virulence [25]. Virulence also was correlated with the development of rope-like structures enmeshed with bacteria and extending between border cells (Figure 2A). The significance of these host-microbe specific phenomema was not clear until extracellular histone was discovered among border cell-secreted proteins [26]. Histone-linked extracellular DNA (exDNA) is a key component of NETs $[1,2]$. Our discovery that histone H4 is among the proteins secreted from plant cells suggested parallels with innate immunity in animals. Like neutrophils, border cells now have been shown to produce exDNA-based traps that protect growing root tips from invasion by fungal pathogens; when the exDNA is removed by treatment with DNase at the time of inoculation, root tip infection increases from $<1 \%$ to $100 \%$ [27]. Staining with DNA-binding molecules such as Sytox green, DAPI, and toluidine blue (Figure 2B,C) reveals structures similar in appearance to NETs [28]. Individual border cells also produce a mucilaginous capsule (Figure 3 ) similar to that appearing on bacterial cells stained with India ink [29]. Both types of extracellular structures are induced in response to pathogens, metals, and other elicitors [23], and both are eliminated in response to DNase I $[27,30]$. Plant pathogens produce exDNase activities whose role in reversal of extracellular trapping will be of interest as an avenue to explore for application in agriculture and medicine $[19,31]$. 
Citation: Curlango-Rivera G, Flores-Lara Y, Cho I, Huskey DA, Xiong Z, Hawes MC (2014) Signals Controlling Extracellular Trap Formation in Plant and Animal Immune Responses. Clin Microbial 3: 166. doi:10.4172/2327-5073.1000166

Page 2 of 3

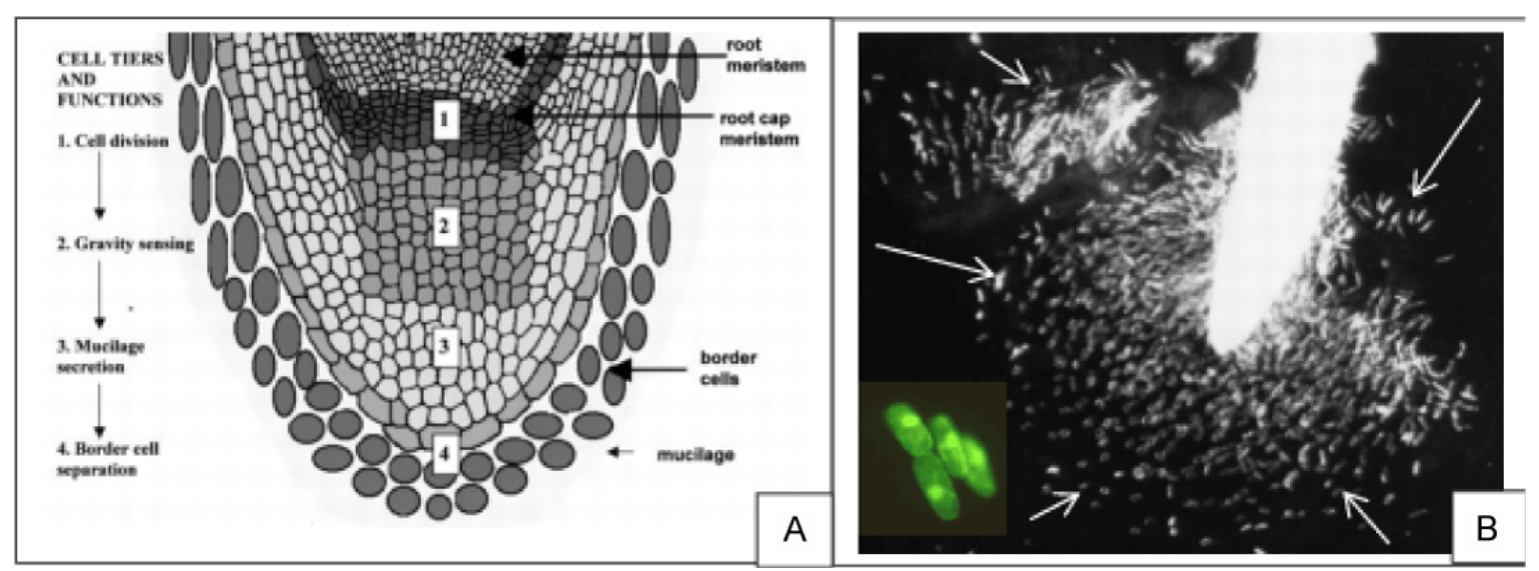

Figure 1: Cell cycle control of border cell production and delivery. (A) Meristematic cells (1) within the root cap undergo cell division and then differentiate into specialized cells (2) that sense gravity and other signals to control direction of root growth. Cells at the cap periphery (3) secrete mucilage as border cells (4) separate into the environment. (B) Upon exposure of the root tip to water, border cells (arrows) disperse instantaneously into suspension. Cell viability in most species is $>90 \%$, as revealed by treatment with the vital stain fluorescein diacetate, which accumulates only within living cells (inset).

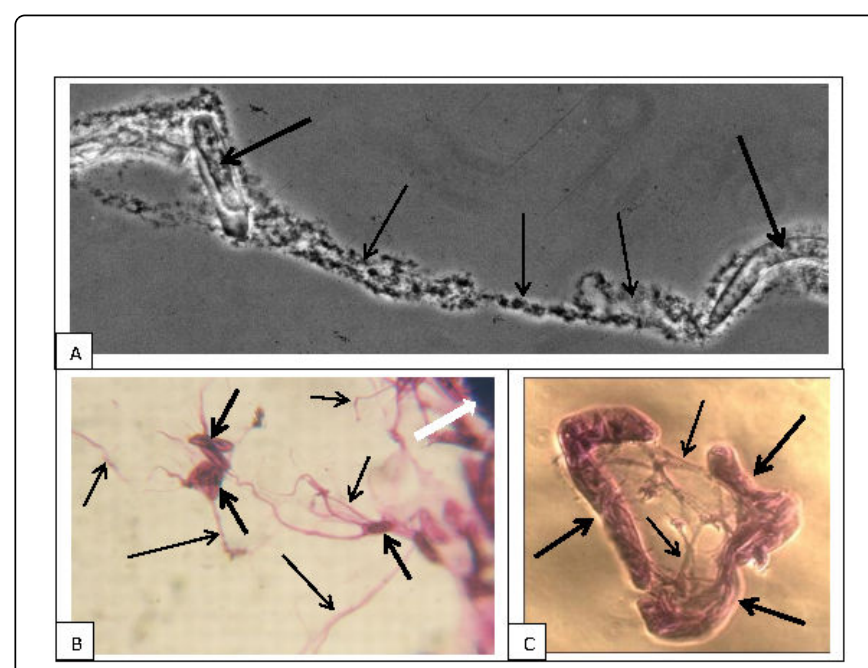

Figure 2: Plant extracellular traps: Development of mucilaginous strands similar in appearance to mammalian NETs. (A) When pathogenic bacteria are incubated with border cells (bold black arrow), conspicuous strands enmeshed with masses of trapped, inert bacteria (black arrow) develop rapidly, leaving the background largely free of actively swimming bacteria. (B) When toluidine blue is added to water as border cells (bold black arrows) disperse from the root cap periphery (white arrow), strands similar in appearance to NETs (black arrows) are revealed instantaneously. (C) Similar strands (black arrows) are evident when toluidine blue is added to detached border cells (bold black arrows).

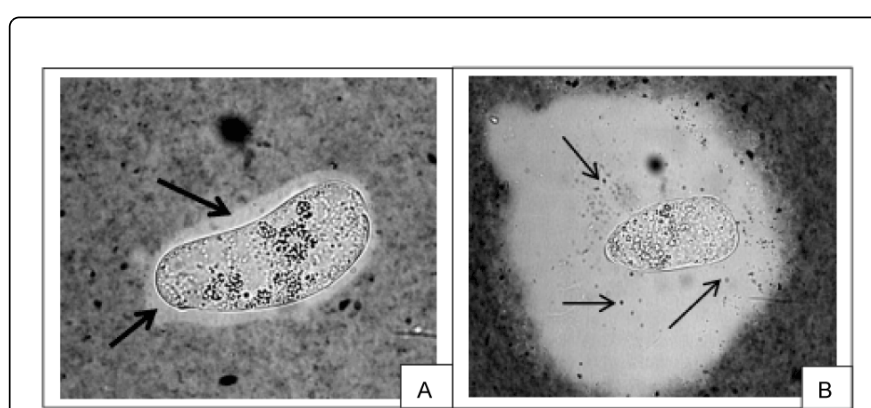

Figure 3: Plant extracellular traps: Capsule formation on individual border cells. (A) As border cells detach from the root cap, in the absence of microbial populations, a small capsule ca 2-3 microns in diameter (bold arrow) is revealed by adding India ink, which does not penetrate the mucilaginous matrix. (B) When pathogenic bacteria are added, the capsule as revealed by India ink expands by $>10$-fold within 5 minutes, and bacteria (arrows) can be seen trapped throughout the expanding matrix.

Plant and animal defense pathways share many common elements [32-35]. As such, plant metabolites have long been of interest in modulating human diseases, with salicylic acid and aspirin as one enduring example of success in application [36]. Plant cells, whose trapping responses can be induced in a synchronous fashion within minutes, may provide a convenient model system to identify signals that control exDNA production and delivery, and to dissect mechanisms by which eukaryotic extracellular trapping occurs [37]. Understanding how such signals from plants may participate in the trapping process in plants, the natural host extracellular environment may help facilitate efforts to use them to control plant and human health [38]. 


\section{References}

1. Brinkmann V, Reichard U, Goosmann C, Fauler B, Uhlemann Y, et al (2004) Neutrophil extracellular traps kill bacteria. Science 303: 1532-1535.

2. Brinkmann V, Zychlinsky A (2012) Neutrophil extracellular traps: is immunity the second function of chromatin? J Cell Biol 198: 773-783.

3. Buchanan JT, Simpson AJ, Aziz RK, Liu GY, Kristian SA, et al. (2006) DNase expression allows the pathogen group A Streptococcus to escape killing in neutrophil extracellular traps. Curr Biol 16: 396-400.

4. Sumby P, Barbian KD, Gardner DJ, Whitney AR, Welty DM, et al. (2005) Extracellular deoxyribonuclease made by group A Streptococcus assists pathogenesis by enhancing evasion of the innate immune response. Proc Natl Acad Sci U S A 102: 1679-1684

5. Guimarães-Costa $\mathrm{AB}$, Nascimento $\mathrm{MT}$, Froment GS, Soares RP Morgado FN, et al. (2009) Leishmania amazonensis promastigotes induce and are killed by neutrophil extracellular traps. Proc Natl Acad Sci U S A 106: 6748-6753.

6. Jenne CN, Wong $\mathrm{CH}$, Zemp FJ, McDonald B, Rahman MM, et al. (2013) Neutrophils recruited to sites of infection protect from virus challenge by releasing neutrophil extracellular traps. Cell Host Microbe 13: 169-180.

7. Urban CF, Reichard U, Brinkmann V, Zychlinsky A (2006) Neutrophil extracellular traps capture and kill Candida albicans yeast and hyphal forms. Cell Microbiol 8: 668-676.

8. Wiersinga WJ, Leopold SJ, Cranendonk DR, van der Poll T (2014) Host innate immune responses to sepsis. Virulence 5: 36-44.

9. Papayannopoulos V, Zychlinsky A (2009) NETs: a new strategy for using old weapons. Trends Immunol 30: 513-521.

10. Medina E (2009) Neutrophil extracellular traps: a strategic tactic to defeat pathogens with potential consequences for the host. J Innate Immun 1: 176-180.

11. Wen F, Shen A, Choi A, Gerner EW, Shi J (2013) Extracellular DNA in pancreatic cancer promotes cell invasion and metastasis. Cancer Res 73: 4256-4266.

12. Papayannopoulos V (2014) Infection: microbial nucleases turn immune cells against each other. Curr Biol 24: R123-125.

13. von Köckritz-Blickwede M1, Nizet V (2009) Innate immunity turned inside-out: antimicrobial defense by phagocyte extracellular traps. J Mol Med (Berl) 87: 775-783.

14. Wartha F, Beiter K, Normark S, Henriques-Normark B (2007) Neutrophil extracellular traps: casting the NET over pathogenesis. Curr Opin Microbiol 10: 52-56.

15. Cooper PR, Palmer LJ, Chapple IL (2013) Neutrophil extracellular traps as a new paradigm in innate immunity: friend or foe? Periodontol 2000 63: 165-197.

16. Sherry S, Goeller JP (1950) The extent of the enzymatic degradation of desoxyribonucleic acid (DNA) in purulent exudates by streptodornase. J Clin Invest 29: 1588-1594

17. Amoako KK, Goto Y, Shinjo T (1993) Comparison of extracellular enzymes of Fusobacterium necrophorum subsp. necrophorum and Fusobacterium necrophorum subsp. funduliforme. J Clin Microbiol 31: 2244-2247.

18. Sánchez M, Colom F (2010) Extracellular DNase activity of Cryptococcus neoformans and Cryptococcus gattii. Rev Iberoam Micol 27: 10-13.

19. Hawes MC, Curlango-Rivera G, Wen F, White GJ, Vanetten HD, et al. (2011) Extracellular DNA: the tip of root defenses? Plant Sci 180: 741-745.
20. Curlango-Rivera G, Hawes MC (2011) Root tips moving through soil: an intrinsic vulnerability. Plant Signal Behav 6: 726-727.

21. Wen F, Brigham LA, Curlango-Rivera G, Xiong Z, Hawes MC (2013) Altered growth and root tip morphology in response to altered expression of a gene expressed in border cells. Plant Soil 373:13-18.

22. Driouich A, Follet-Gueye M, Vicre-Gibouin M, Hawes MC (2013) Root border cells and secretions as critical elements in plant host defense. Curr Opin Plant Biol 16:1-5

23. Hawes MC, Curlango-Rivera G, Xiong Z, Kessler JO (2012) Marschner review. Roles of root border cells in plant defense and regulation of rhizosphere microbial populations by extracellular DNA 'trapping'. Plant Soil 355: 1-15

24. Ponce G, Barlow PW, Feldman LJ, Cassab GI (2005) Auxin and ethylene interactions control mitotic activity of the quiescent centre, root cap size, and pattern of cap cell differentiation in maize. Plant Cell Environ 28: 719-732.

25. Hawes MC, Pueppke SG (1987) Correlation between binding of Agrobacterium tumefaciens by root cap cells and susceptibility of plants to crown gall. Plant Cell Rep 6: 287-290.

26. Wen F, Curlango-Rivera G, Hawes MC (2007) Proteins among the polysaccharides: a new perspective on root cap slime. Plant Signal Behav 2: 410-412.

27. Wen F, White GJ, VanEtten HD, Xiong Z, Hawes MC (2009) Extracellular DNA is required for root tip resistance to fungal infection. Plant Physiol 151: 820-829.

28. Hamaguchi S, Seki M, Yamamoto N, Hirose T, Matsumoto N, et al (2012) Case of invasive nontypable Haemophilus influenzae respiratory tract infection with a large quantity of neutrophil extracellular traps in sputum. J Inflamm Res 5: 137-140.

29. Weinberger DM, TrzciÅ,ski K, Lu YJ, Bogaert D, Brandes A, et al. (2009) Pneumococcal capsular polysaccharide structure predicts serotype prevalence. PLoS Pathog 5: e1000476.

30. Curlango-Rivera G, Huskey DA, Mostafa A, Kessler JO, Xiong Z, et al (2013) Intraspecies variation in cotton border cell production: rhizosphere microbiome implications. Am J Bot 100: 1706-1712.

31. Tran TM, Hawes MC, Allen C (2013) Extracellular DNases contribute to virulence of Ralstonia solanacearum. Phytopath 103:147-148.

32. González-Lamothe R, Mitchell G, Gattuso M, Diarra MS, Malouin F, et al. (2009) Plant antimicrobial agents and their effects on plant and human pathogens. Int J Mol Sci 10: 3400-3419.

33. Land WG, Messmer K (2012) The danger theory in view of the injury hypothesis: 20 years later. Front Immunol 3: 349.

34. Newman MA, Sundelin T, Nielsen JT, Erbs G (2013) MAMP (microbeassociated molecular pattern) triggered immunity in plants. Front Plant Sci 4: 139 .

35. Pisetsky DS (2012) The origin and properties of extracellular DNA: from PAMP to DAMP. Clin Immunol 144: 32-40.

36. Norn S1, Permin H, Kruse PR, Kruse E (2009) From willow bark to acetylsalicylic acid. Dan Medicinhist Arbog 37: 79-98.

37. Curlango-Rivera R, Duclos DV, Ebolo JJ, Hawes MC (2010) Transient exposure of root tips to primary and secondary metabolites: Impact on root growth and production of border cells. Plant and Soil 306: 206-216.

38. Kirchner T, Hermann E, Möller S, Klinger M, Solbach W, et al. (2013) Flavonoids and 5-aminosalicylic acid inhibit the formation of neutrophil extracellular traps. Mediators Inflamm 2013: 710239. 